5. Михайлов В.В., Лобанов В.Б. Вооруженное противостояние на Тереке на рубеже 1918-1919 гг. // Военноисторический журнал. 2019. № 5. С. 32-37.

6. Пученков А.С. Размышляя о Гражданской войне // Вестник Северного (Арктического) федерального университета. Серия: Гуманитарные и социальные науки. 2020. № 4. С. 33-37.

7. Пученков А.С. Южнорусское белое движение и Польша в годы Гражданской войны (1919-1920 гг.) // Вопросы истории. 2020. № 3. С. 53-66.

\title{
Камбиев А.М. \\ Пшемахо Коцев - один из лидеров движения горцев Северного Кавказа за независимость в период Революции и Гражданской войны
}

Санкт-Петербургский государственный университет аэрокосмического приборостроения (Россия, Санкт-Петербург)

doi: 10.18411/trnio-01-2022-08

\section{Аннотация}

В статье рассматривается проблематика, связанная с общественно-политической деятельностью известного горского либерально-националистического деятеля периода Революции и Гражданской войны в России Пшемахо Коцева. В начале Гражданской войны в регионе он поочередно был комиссаром и министром всех антибольшевистских правительств, пока в итоге в начале 1919 г. не стал во главе Горского правительства. Несмотря на расхождения с белогвардейцами по поводу судеб региона, пошел на сотрудничество с ними. Делается вывод о том, что в годы Второй мировой войны, несмотря на неприятие коммунистического режима, не стал на путь коллаборационизма.

Ключевые слова: Коцев, Революция, Гражданская война, горцы, казаки, Деникин, Горское правительство, Северный Кавказ.

\section{Abstract}

The article deals with the problems related to the socio-political activities of the famous mountain liberal-nationalist figure of the period of Revolution and Civil War in Russia, Przemakho Kotsev. At the beginning of the Civil War in the region, he was alternately commissar and minister of all anti-Bolshevik governments, until eventually, in early 1919, he became the head of the Mountain government. Despite disagreements with the White Guards about the fate of the region, went to cooperate with them. It is concluded that during the Second World War, despite the rejection of the communist regime, he did not take the path of collaboration.

Keywords: Kotsev, Revolution, Civil War, mountaineers, Cossacks, Denikin, Mountain government, North Caucasus.

Революция и Гражданская война на Северном Кавказе 1917-1920 гг. в силу этнического и религиозного разнообразия имела ряд региональных особенностей, носила ожесточенный характер, вызванный к тому же влиянием различных внешних факторов [6, с. 35]. Местная национальная гражданская и военная интеллигенция играла активную роль в военно-политических процессах региона на разных сторонах конфликта. Одним из ярчайших представителей горской либерально-националистической интеллигенции был Пшемахо Коцев, одно время, в 1919 г., возглавлявший Горское правительство.

Биография Пшемахо Тамашевича Коцева достаточно характерна для отпрысков состоятельных и образованных семей горских верхов на рубеже 19-20 вв. Родившись в 1884 г. в семье состоятельного кабардинского узденя, он получил начальное образование в Пятигорске, окончил курс Новороссийской гимназии и поступил на восточный факультет столичного университета, однако позже перешел на юридический факультет СанктПетербургского университета и закончил его в 1910 г. 22 ноября этого же года П. Коцев был зачислен младшим кандидатом на судебную должность при Екатеринодарском окружном суде. 
Стоит отметить, что П. Коцева, как и многих будущих деятелей горского движения за независимость, отличала абсолютная лояльность императорской власть. Вся их «оппозиционность» заключалась зачастую в публицистической деятельности, которая была попыткой привлечь внимание к тем или иным злободневным вопросам, в данном случае к проблемам Северного Кавказа и горцев.

После свержения монархии в России был сформирован временный Кубанский областной гражданский исполнительный комитет. От черкесов в числе других членом этого комитета был избран присяжный поверенный П. Коцев, который в то время жил и работал в Екатеринодаре. Считается, что именно с этого события начинается активная фаза его недолгой политической деятельности.

Вернувшись из Екатеринодара на Родину, Коцев был избран членом Нальчикского окружного гражданского исполнительного комитета. Он принимал активное участие в работе I-го съезда Союза объединенных горцев Северного Кавказа и Дагестана, проходившего в начале мая 1917 г., был избран в руководство ЦК Союза [1, с. 74]. 18 мая 1917 г. во Владикавказе собрался областной съезд делегатов сельских и городских исполнительных комитетов и Советов рабочих и солдатских депутатов для выработки и утверждения «Положения о временном самоуправлении Терской областью». По результатам этого съезда П. Коцев стал председателем Терского областного гражданского исполнительного комитета, высшего органа государственной власти Временного правительства в Терской области.

21 сентября 1917 г. во Владикавказе под председательством Абдул-Меджида Чермоева был открыт II-ой съезд Союза объединенных горцев Северного Кавказа [5, с. 135]. Одним из товарищей председателя был избран председатель Терского областного исполнительного комитета, член ЦК Союза объединенных горцев П. Коцев.

В середине октября 1917 г. во Владикавказе открылась конференция казачьих войск, горцев Кавказа, вольных народов степей, которая завершилась подписанием Союзного договора 20 октября 1917 г. От имени Союза объединенных горцев договор подписали Б.К. Далгат, В.-Г. Э. Джабагиев, И.В. Баев, П. Коцев. После подписания союзного договора было создано правительство Юго-Восточного Союза под председательством В. Харламова. В новосозданное правительство от Союза объединенных горцев вошли деятели горского движения, в том числе и П. Коцев.

После захвата власти большевиками в Петрограде терский атаман М.А. Караулов 15 ноября 1917 г. издал приказ о своем вступлении в управление казачьими отделами Терской области. В тот же день ЦК Союза объединенных горцев объявил о распространении своей юрисдикции на территории с горским населением, было сформировано правительство. Его возглавил председатель Союза объединенных горцев Абдул-Меджид Чермоев. П. Коцев в нем стал министром внутренних дел.

Понимание того, что в одиночку невозможно противостоять большевикам, привело к тому, что 1 декабря 1917 г. казаки и горцы образовали Временное Терско-Дагестанское правительство. В обращении правительства к народу от 8 декабря 1917 г. население извещалось о формировании правительства, в котором комиссаром по делам общественного спокойствия был назначен Пшемахо Коцев.

Новое правительство продержалось недолго, в марте 1918 г. большевики захватили власть на Тереке и провозгласили создание Терской советской республики в составе РСФСР. Деятели горского либерального направления продолжили борьбу. Делегация горской фракции бывшего Временного Терско-Дагестанского правительства во главе с А.-М. Чермоевым 11 мая 1918 г. на Батумской мирной конференции провозгласила создание независимой от Советской России Горской республики.

После провозглашения независимости Горской республики А.-М. Чермоев стал председателем правительства. Начался активный поиск путей международного признания и помощи в строительстве нового государства. Активная помощь пришла со стороны Османской империи. 4 октября 1918 г. в Дербент прибыла военно-дипломатическая 
делегация во главе с черкесом Юсуф Иззет-пашой. Объединенная турецко-горская армия выбила в ноябре войска Л. Бичерахова из Порт-Петровска. Поражение стран Четверного союза в Первой мировой войне и появление англичан в середине ноября 1918 г. изменило военно-политическую ситуацию на Кавказе.

П. Коцев как представитель Горского правительства был приглашен в Баку английским командованием для переговоров. В итоге английское командование признало дефакто существование Горской республики до окончательного решения вопроса на Парижской мирной конференции. Англичане предложили П. Коцеву сформировать новое коалиционное правительство, что и было сделано в январе 1919 г.

На рубеже 1918-1919 гг. под ударами Добровольческой армии большевики были разгромлены на территории Терека [2, с. 45]. Новая военно-политическая ситуация внесла существенные изменения во внешнюю и внутреннюю политику Горской республики. Обе власти - и добровольцы, и горские деятели претендовали на господство в терскодагестанском регионе.

На съезде чеченского народа в марте 1919 г., в ходе состоявшейся беседы П. Коцева с генералом В.П. Ляховым, тогдашним главноначальствующим и главнокомандующим войсками Терско-Дагестанского края ВСЮР, было выявлено концептуальное различие в подходах горцев и добровольцев к проблеме, связанной с военно-политическим будущим Северного Кавказа.

Между тем положение Горской республики катастрофически ухудшалось. К этому времени в горском парламенте сложилась оппозиция против правительства П. Коцева. Кроме этого, большевики, открыто подкупая сторонников, формировали свои вооруженные силы. «Армия» Горского правительства насчитывала не больше тысячи человек, к тому же она была ненадежна, многие сочувствовали большевикам. С другой стороны, горское офицерство практически открыто поддерживало белогвардейцев, действовавших на Северном Кавказе. Оно было готово перейти на службу к генералу А.И. Деникину в любую минуту [7, с. 60]. Сознавая это, 12 мая 1919 г. правительство П. Коцева подало в отставку.

После отставки кабинета П. Коцева новый кабинет министров возглавил проденикинский генерал М. Халилов. В то время, когда последний был занят организацией своего правительства, вооруженные силы Терско-Дагестанского края ВСЮР 22 мая заняли Петровск и Дербент [3, с. 60].

В июне 1919 г. П. Коцев был арестован деникинцами и некоторое время провел в Пятигорской тюрьме. То, что бывший лидер горского движения за независимость был выпущен белогвардейцами, остался на территории, подконтрольной ВСЮР [4, с. 1145], говорит об определенной степени лояльности П. Коцева новой власти на Северном Кавказе. Более того, он продолжил свою общественно-политическую деятельность. В частности, он принял участие в состоявшемся в начале января 1920 г. в Екатеринодаре съезде черкесов Кубанского края в качестве одного из его руководителей.

В начале марта 1920 г. П. Коцев покинул Екатеринодар, пересек грузинскую границу и по черноморскому побережью добрался до Сухуми. В Грузии П. Коцев продолжил активно участвовать в деятельности горского движения. Здесь он был посажен грузинскими властями в тюрьму, был выпущен, эмигрировал в Турцию и 25 декабря 1920 г. оказался с соратниками в Трабзоне.

Спустя несколько лет после провозглашения Турецкой республики П.Т. Коцев принял турецкое гражданство, продолжая активно участвовать в деятельности горской эмиграции. В годы Второй мировой войны, оставаясь на антибольшевистской платформе, П.Т. Коцев отверг любые формы сотрудничества с нацистской Германией.

В заключение следует отметить, что П. Коцев являл собой редкий пример честного либерального интеллигента из горских верхов, верой и правдой служившего интересам Российской империи на юридическом поприще, пытался привлечь внимание общественности и правительства к проблемам своего родного Северного Кавказа на публицистической ниве. После падения монархии в России включился в общественно-политическую деятельность, 
стараясь нормализовать обстановку в регионе. Как и многие либерально настроенные горцы, не принял власть большевиков, стал одним из лидеров горского национальнодемократического движения, на короткий период стал во главе Горской республики. В отличие от многих своих соратников, остался на территории, занятой ВСЮР, сотрудничал с белогвардейцами на почве общего неприятия большевизма. После гибели Белого движения на Кавказе был вынужден покинуть Родину, эмигрировал в Турцию, где продолжил активно заниматься вопросами, связанными с горской эмиграцией. Во время Второй мировой войны, несмотря на свое крайнее неприятие Советской власти, отказался встать на путь коллаборационизма с Германией.

1. Артемьев А.С., Лобанов В.Б. Владикавказский съезд горских народов Северного Кавказа в мае 1917 г. // Современная научная мысль. 2019. № 2. С. 73-77.

2. Артемьев А.С., Лобанов В.Б. Добровольческая армия в Терской области: Конец 1918 - первая половина 1919 гг. // Современная научная мысль. 2019. № 1. С. 43-50.

3. Добрякова Н.А., Донин А.Я., Лобанов В.Б. Антибольшевистские силы Терско-Дагестанского региона в период Гражданской войны 1917-1920 гг. // Современная научная мысль. 2019. № 2. С. 58-67.

4. Камбиев А.М. Азербайджанская Демократическая Республика и ее политика в отношении Терека и Дагестана (вторая половина 1919 - начало 1920 гг.) // Historia provinciae - журнал региональной истории. 2020. Т. 4. № 4. С. 1140-1173.

5. Камбиев А.М. Нажмуддин Гоцинский - активный деятель Революции и Гражданской войны на Северном Кавказе (1917-1920) // Современная научная мысль. 2021. № 2. С. 135-139.

6. Пученков А.С. Размышляя о Гражданской войне // Вестник Северного (Арктического) федерального университета. Серия: Гуманитарные и социальные науки. 2020. № 4. С. 33-37.

7. Пученков А.С. Южнорусское белое движение и Польша в годы Гражданской войны (1919-1920 гг.) // Вопросы истории. 2020. № 3. С. 53-66.

\section{Касарова В.Г., Сологян А.А. \\ Характеристика мусульманско-коптских отношений в Египте и тенденция их развития}

Московский автомобильно-дорожный государственный технический университет (МАДИ) (Россия, Москва)

doi: 10.18411/trnio-01-2022-09

\section{Аннотация}

В статье рассматриваются мусульманско-коптские отношения на протяжении многовековой истории, дается общая характеристика и тенденция развития этих отношений в Египте. Дается серьезный анализ и оценка дальнейших перспектив их взаимодействия. Статья содержит выводы о мусульманско-копских отношениях в историческом контексте. Данная статья будет интересна всем интересующимся историей Египта.

Ключевые слова: копты, Египет, взаимодействие, многовековая история, этапы развития, мусульманско-коптские отношения, межэтнический характер.

\section{Abstract}

The article examines the Muslim-Coptic relations throughout the centuries-old history, gives a general characteristic and the tendency of the development of these relations in Egypt. A serious analysis and assessment of further prospects of their interaction is given. The article contains conclusions about Muslim-Kop relations in a historical context. This article will be of interest to everyone interested in the history of Egypt.

Keywords: copts, Egypt, interaction, centuries-old history, stages of development, MuslimCoptic relations, interethnic character.

В современном мире часто приходится возвращаться к вопросам национальной идентичности в разных частях земного шара. «Один из самых сложных вопросов, который является актуальным в настоящее время: исторически сложившиеся взаимоотношения 